\title{
SNAHY O OBMEDZENIE VYSOKOŠKOLSKÉHO ŠTÚDIA ŽIEN V OBDOBÍ SLOVENSKÉHO ŠTÁTU
}

\author{
EVA ŠK O R VA N K O V Á
}

\begin{abstract}
ŠKORVANKOVÁ, Eva. Attempts to limit university study by women in the time of the Slovak state. Historický časopis, 2018, roč. 66, č. 4, pp. 649-670. Bratislava.

The movement away from the democratic political principles of the Czechoslovak State during the period of autonomy and after the declaration of the Slovak State was also reflected in changes in the status of Slovak women in the political and social life of the country. This study focuses on the restriction and limitation of the education of girls and women in the wartime Slovak Republic. A very common argument for this policy of the Slovak conservative ruling elites was to achieve an idealized image of the Slovak woman as mother and housewife and to solve the social problems of the new State.

Key words: Women. Slovak Republic 1939-1945. Education. Slovak University (Universitas Slovaca Istropolitana) in Bratislava.

DOI: https://doi.org/10.31577/histcaso.2018.66.4.4
\end{abstract}

Diskurz o vzdelaných ženách tvoril neoddelitel'nú súčast' verejných debát o ich poslaní a úlohe v slovenskej spoločnosti. ${ }^{1}$ Slovenské politické elity diskutovali o otázke vzdelávania dievčat $\mathrm{v}$ kontexte predstáv o ich profesijnej a spoločenskej realizácii. Vychádzali z idey o ,prirodzenom“ mieste ženy v rodine a o odlišnostiach medzi pohlaviami. Žena sa mala realizovat' v súkromnej sfére $-\mathrm{v}$ rodine a v domácnosti. Preto aj pohl'ad na ciele a účel dievčenského vzdelávania bol ovplyvnený týmto názorom, ktorý bol všeobecne rozšírený v tábore slovenskej politickej a intelektuálnej elity. ${ }^{2}$ Úloha ženy ako matky a ženy ako domácej panej bola považovaná za službu či povinnost’ národu. Postavenie žien žijúcich na území dnešného Slovenska sa zásadne zmenilo po vzniku Československej republiky. Novovzniknutý štát bol demokratickou republikou, ktorá poskytovala ženám rovnaké občianske a politické práva ako mužom. Zároveň boli v krajine odstrá-

1 DUDEKOVÁ, Gabriela. Diskurz o poslaní vzdelaných žien pred a po roku 1918. In DUDEKOVÁ, Gabriela a kol. Na ceste $k$ modernej žene: Kapitoly z dejín rodových vzt'ahov na Slovensku. Bratislava: Veda, 2011, s. 95. ISBN 9788022411899.

2 Bližšie sa tejto téme venuje HOLLÝ, Karol. Ženská emancipácia: Diskurz slovenského národného hnutia na prelome 19. a 20. storočia. Bratislava: Prodama, 2011, 178 s. ISBN 9788089396160. 
nené formálne bariéry pre získanie adekvátneho vzdelania a prístupu k zamestnaniu. V medzivojnovom období sa postupne začal zvyšovat' podiel pracujúcich (ekonomicky aktívnych) žien. ${ }^{3}$ Pozitívom bolo narastanie počtu dievčat na stredných školách a na univerzitách. ${ }^{4}$ Zvyšovalo sa množstvo absolventiek škôl pre ženské povolania. Získané vzdelanie a kvalifikácia umožnili širšie uplatnenie žien vo vede a v povolaniach vyžadujúcich si vysokoškolskú kvalifikáciu. ${ }^{5}$

\section{Prvé kroky k obmedzeniu vzdelávania dievčat}

V politickom diskurze na Slovensku sa udržiaval konzervatívny pohl'ad na poslanie žien. Napriek nesporne pozitívnym skúsenostiam so vzdelanými a intelektovo nadanými ženami sa v spoločnosti udržiavali predsudky o ženskej emocionalite a menšej intelektuálnej nadanosti, ktoré ich hendikepovali pre vyššie vzdelávanie. Edukácia a získanie kvalifikácie znamenalo pre ženy možnost' nadobudnút' platené zamestnanie, a tým aj existenčné zabezpečenie a sociálnu mobilitu. Možnost' dosiahnut' vzdelanie a nájst' si platenú prácu bola identifikátorom miery emancipácie žien v spoločnosti. Vo verejnom priestore sa preto téma vzdelávania žien automaticky prepojila s otázkou ich zamestnávania a ich profesionálnej realizácie vo verejnom priestore, mimo rámca rodiny. Snahy obmedzit' prístup k vzdelaniu boli motivované predstavami o „prirodzenom“ poslaní žien a ich realizovaní v súkromnej sfére, v materstve a manželstve. Po vyhlásení autonómie 6. októbra 1938 a s nástupom autoritatívneho režimu Hlinkovej slovenskej l'udovej strany (HSL'S) sa tieto názory prejavili konkrétnymi snahami

3 K nárastu zamestnanosti v medzivojnovom období došlo v skupine tzv. pomáhajúcich členov rodiny, čo súviselo s prevažne agrárnym charakterom Slovenska. Postupne sa zvyšoval počet žien robotníčok a úradníčok (do tejto skupiny patrili aj učitel'ky). Bližšie k zamestnanosti žien v medzivojnovom období pozri TIŠLIAR, Pavol. Ekonomická aktivita obyvatel'stva Slovenska v medzivojnovom období so zretel'om na zamestnanost' žien. In DUDEKOVÁ, Gabriela a kol. Na ceste k modernej žene: Kapitoly z dejín rodových vzt'ahov na Slovensku. Bratislava: Veda, 2011, s. 343-364. ISBN 9788022411899.

4 Takzvaným malým školským zákonom z júna 1922 bola na meštianskych školách zavedená koedukácia, ktorá umožnila štúdium dievčat na meštianskych školách. Školy pre ženské povolania prešli rozsiahlou modernizáciou. Nové predmety v osnovách umožňovali prípravu dievčat pre samostatnost' v podnikaní a osobnom živote. KÁZMEROVÁ, Lubica. Riadiace orgány školstva na Slovensku a vzdelávací systém v rokoch 1918 - 1945. KÁZMEROVÁ, L’ubica a kol. Premeny v školstve a vzdelávaní na Slovensku (1918 - 1945). Bratislava: Prodama, 2012, s. 21 a 24. ISBN 9788022415361.

5 Vysokoškolské vzdelanie si vyžadovalo napr. povolanie právničky či lekárky. V medzivojnovom období postupne narastal počet študentiek práva aj na Univerzite Komenského (počet sa pohyboval okolo 30). Bližšie ZAVACKÁ, Katarína. Právničky v Československej republike: Absolventky práva a právna prax v Československu po roku 1918. In DUDEKOVÁ, Gabriela a kol. Na ceste k modernej žene: Kapitoly z dejín rodových vzt'ahov na Slovensku. Bratislava: Veda, 2011, s. 586-598. ISBN 9788022411899; GAJDOŠOVÁ, Martina - KERECMAN, Peter. Prvé ženy v slovenskej advokácii. Bratislava: Veda, 2015, 320 s. ISBN 9788022414302. 
o obmedzenie verejného a profesijného pôsobenia žien, ako aj ženského vzdelávania. ${ }^{6}$ Otázka zamestnávania vydatých žien sa stala zásadným politickým a sociálnym problémom druhej Česko-Slovenskej republiky, najmä v súvislosti s nadbytkom štátnych a verejných zamestnancov po územných stratách následkom Mníchovskej dohody a 1. Viedenskej arbitráže. Vel'kej kritike bolo vystavené tzv. hromadenie príjmov v rodine, t. j. zárobková činnost' oboch manželov, najmä ak manželstvo bolo bezdetné. V decembri 1938 ústredná vláda v Prahe prijala vládne nariadenie o prepustení vydatých žien zo štátnej služby, pokial' ich manželia (štátni zamestnanci) mali dostatočný príjem. ${ }^{7}$ Vyriešenie problému zamestnanosti vydatých žien na Slovensku mala priniest' autonómna vláda. Podl'a vládneho programu mali dostat' prednost' pri zamestnávaní mladí muži, aby tí boli schopní uzatvárat' manželstvá a zakladat' si rodiny. Vládny program na jednej strane nepopieral práva žien na vyššie vzdelanie, ale vyslovil sa proti koedukácii. ${ }^{8}$ Jej zrušením mali byt' položené základy zdravej výchovy mladej populácie. V oblasti vysokoškolského štúdia zásahy autonómnej vlády smerovali najmä k odstráneniu českých profesorov z univerzity a obmedzeniu štúdia pre českých a židovských študentov. ${ }^{9}$ Následne sa začalo verejne diskutovat' o ob-

6 Podobné opatrenia boli realizované aj na príklade iných autoritatívnych režimov. V prípade Nemecka môžeme hned' po nacistickom prevzatí moci sledovat' rôzne snahy a opatrenia, ktorých ciel’om bolo zníženie zamestnanosti žien (zákonom o znížení nezamestnanosti, podmienkami na udelenie manželských pôžičiek, pokračovaním vládnej kampane proti hromadeniu príjmov, zákazom pre ženy pracovat'v advokátskej a súdnej praxi) a obmedzenie vzdelávania žien (zavedenie kvót na vysokoškolské štúdium, obmedzenie vedeckej činnosti, zásahy do stredoškolského vzdelávania). Väčšina týchto diskriminačných opatrení bola ale v dôsledku nedostatku pracovných síl (najmä kvôli zavedeniu brannej povinnosti a zbrojnému programu) postupne odstránená. Bližšie STEPHENSON, Jill. Women in Nazi Society. London: Croom Helm, 1975, s. 95-115, 132-135. ISBN 9780415534093; BURLEIGH, Michael - WIPPERMANN, Wolfgang. Rasistický stát: Německo 1933-1945. Praha: Columbus, 2010, s. 256-258. ISBN 978802492619.

7 Dôležité uznesenie ministerskej rady. In Slovenský deník, 25. decembra 1938, roč. XXI, č. 298, s. 5. Vládne nariadenie ústrednej vlády č. 379/1938 Sb. z. a n. z 21. decembra 1938.

8 Vyhlásenie vlády Slovenskej krajiny prednesené Jozefom Tisom. In FABRICIUS, Miroslav - HRADSKÁ, Katarína (eds.). Jozef Tiso: Prejavy a články. Zv. II (1938 - 1944). Bratislava: AEP, 2007, s. 77 a 82. ISBN 9788088880462.

9 Roku 1938 pribúdali útoky na českých a židovských študentov na Univerzite Komenského v Bratislave. V novembri 1938 bolo z univerzity vylúčených 465 židovských (alebo považovaných za židovských) študentov. Členovia Spolku slovenských medikov žiadali zavedenie numerus nullus pre príslušníkov židovskej národnosti alebo viery na 25 rokov a potom numerus clausus. Na právnickej fakulte požadovali predstavitelia študentov zákaz štúdia na fakulte pre židovských študentov. Bližšie NIŽŇANSKÝ, Eduard. Židovská komunita na Slovensku medzi československou parlamentnou demokraciou a slovenským štátom v stredoeurópskom kontexte. Prešov: Universum, 1999, s. 116-117. ISBN 8096775332.

V akademickom roku 1938/1939 študovalo na jednotlivých fakultách celkovo 20 židovských študentov, v nasledujúcom akademickom roku už len 12. Po prijatí nariadenia č. 255 o úprave 
medzení počtu študujúcich dievčat a žien aj na Slovenskej univerzite. ${ }^{10}$ Najmä v tlači sa objavovali názory o ,zbytočnosti“ vysokoškolského štúdia pre ženy. V akademickom roku 1938/1939 študovalo na Slovenskej univerzite v Bratislave celkovo 314 žien (34 na právnickej fakulte, 82 na lekárskej fakulte a najviac 198 na filozofickej fakulte). ${ }^{11}$

Priestorom pre diskusie o vzdelávaní dievčat a ich perspektívach v novom konzervatívnom a autoritatívnom ideologickom rámci autonómneho Slovenska bola predovšetkým tlač. V článkoch sa diskutovalo hlavne o zrušení koedukácie a o zmysle a ciel'och dievčenského vzdelávania. Niektorí autori sa prikláňali $\mathrm{k}$ názoru, že vzdelávanie malo dievčatá pripravit' na materstvo a vedenie domácnosti a len „,v niektorých prípadoch mimoriadneho nadania $i k$ vyššej činnosti duševnej ". ${ }^{12}$ Preto len nadaným študentkám malo byt' umožnené štúdium, ale väčšina dievčat sa mala pripravovat' na praktické zamestnania. Do učebných osnov pre stredné školy, eventuálne pre dievčenské stredné školy po zrušení koedukácie mali byt' zavedené praktické predmety, ktoré mali dievčatá pripravit' na úlohu budúcej matky a gazdinky. Najprimeranejšie vzdelávanie pre ženy sa malo realizovat' na odborných školách pre ženské povolania a na školách gazdinských. Aj tieto školy ale mali prejst' premenou, pretože sa mali viac prispôsobit' prostrediu slovenskej dediny, mali byt' skromnejšie a jednoduchšie. ${ }^{13}$ Niektorí autori, ktorí sa zapojili do debát, poukazovali na potrebu prepojit' tému vzdelávania dievčat s populačnou politikou štátu. Zrušenie koedukácie a navštevovanie výlučne dievčenských škôl mali dievčatá vychovávat' všestranne , $k$ najvznešenejšiemu povolaniu, $k$ rodinnému životu i $k$ materstvu ". ${ }^{14}$

\section{Vzdelávanie dievčat a diskusie o profesijnom uplatnení žien}

Po vyhlásení Slovenského štátu v marci 1939 mohla vládnuca HSL'S realizovat' svoje ideologické a politické koncepty a ciele. V rámci budovania autoritatív-

niektorých právnych pomerov Židov vo veciach školstva a vzdelania zo dňa 11. októbra 1940 boli židovskí študenti vylúčení zo všetkých vysokých a stredných škôl a ústavov. Pät' rokov slovenského školstva. Bratislava: Štátne nakladatel'stvo, 1944, s. 318-319.

10 Pôvodne Univerzita Komenského. Vedenie univerzity na podnet autonómnej vlády zmenilo 26. januára 1939 jej názov na Slovenská univerzita (Universitas Slovaca Istropolitana), ktorý bol potvrdený zákonom z 3. júla 1940.

11 DOLAN, Ondrej - BARTL, Július. Bratislavská univerzita v rokoch 1938 - 1945. In Historica: Sborník Filozofickej fakulty Univerzity Komenského, 1966, roč. 17, s. 27.

12 POCKODY, Štefan. O vzdelaní žien v súvise s ich poslaním. In Slovenský deník, 16. decembra 1938, roč. 21, č. 290, s. 3; POCKODY, Štefan. O vzdelaní žien v súvise s ich poslaním. In Slovák, Vianoce 1938, roč. 20, č. 293, s. 22.

13 POCKODY, ref. 12, s. 3.

14 FILKORN, Eugen. Nová žena v novom slovenskom živote. In Nová žena, 1939, roč. 2, č. 2, s. 2-3. 
neho politického režimu vládnuca elita pristúpila k radikálnym opatreniam aj v oblasti školstva a vzdelávania. Odvolávajúc sa na vel'ký nadbytok učitel'ov bez pracovného miesta, ktorý súvisel so stratou území po 1. Viedenskej arbitráži v novembri 1938 a následne po vojnovom konflikte s Mad'arskom v marci 1939, pristúpila slovenská vláda k radikálnym opatreniam. ${ }^{15}$ Zákonom č. 246/1939 S1. z. o úprave služobného pomeru vydatých učiteliek, ktorý bol prijatý 28. septembra 1939, boli zo zamestnania prepustené vydaté učitel'ky. ${ }^{16}$ Podobným spôsobom ako $\mathrm{v}$ prípade vydatých učiteliek sa riešilo aj prepúšstanie vydatých štátnych zamestnankýň. ${ }^{17}$ Prepustenie vydatých učiteliek a úradníčok zo služobného pomeru otvorilo diskusie o perspektívach d'alšieho uplatnenia žien v hospodárskom a sociálnom živote krajiny. Táto diskusia sa preniesla aj do sféry školstva. Bolo potrebné „vyriešit““ otázky budúceho vzdelávania žien, vyjasnit’ názory na očakávanú vzdelanostnú úroveň žien aj vzhl’adom na reálne problémy ich uplatnenia $\mathrm{v}$ pracovnom procese.

Vel'ký priestor v diskusiách o vzdelávaní dievčat bol nad'alej venovaný otázke koedukácie v kontexte kvalitného stredoškolského vzdelávania. Na jednej strane tábor podporovatel'ov koedukácie argumentoval potrebou spoločného vzdelávania a kultivovania oboch pohlaví. Na druhej strane ale pribúdalo zástancov odstránenia koedukácie, pričom sa odvolávali na názory pápeža Pia XI., ktorý sa v encyklike $O$ krestanskej výchove mládež $e^{18}$ postavil proti nej, lebo spoločné vzdelávanie dievčat a chlapcov vraj bolo neprípustné kvôli odlišnostiam mužského a ženského pohlavia. Chlapci a dievčatá nemali dostat' rovnakú výchovu, najmä v období dospievania. Tento názor prevzal mesačník katolíckeho Spolku sv. Vojtecha Kultúra, ${ }^{19}$ v ktorom bola jednoznačne odmietnutá koedukácia. Minister školstva a národnej osvety Jozef Sivák sa tiež postavil proti koedukácii, ktorá údajne spôsobovala „mravnú skazenost".$^{20}$ Zároveň ale pripustil problémy, ktoré prinesie zrušenie koedukácie pre vzdelávanie dievčat, ked’že najmä dievčenských gymnázií bolo podstatne menej. Na stránkach ženského časopisu

15 Minister školstva Jozef Sivák odhadol, že z odstúpených území bolo evakuovaných 766 učitel'ov štátnych škôl, o miesta sa ale hlásili aj mladí absolventi maturitného ročníka 1939 a učitelia vo výpomocných pozíciách. Po obsadení všetkých vol’ných pracovných pozícií tak bez miesta bolo ešte približne 900 učitel'ov. Pät' rokov slovenského školstva, ref. 9, s. 97.

16 Nové slovenské školstvo II. Bratislava: Ministerstvo školstva a národnej osvety, 1940, s. 8.

17 Zákon č. 150/1940 Sl. z. o úprave služobného pomeru vydatých štátnych zamestnankýň a o zmene niektorých ustanovení vládneho nariadenia č. 380/1938 Sb. z. a n. o úsporných opatreniach bol prijatý 5 . júna 1940 .

18 Encyklika Pia XI. Divini Illius Magistri [O krestanskej výchove mládeže] (31. decembra 1929). Dostupné na internete: <http://w2.vatican.va/content/pius-xi/en/encyclicals/documents/hf_p-xi_enc_31121929_divini-illius-magistri.html>.

19 BAČA. Je koedukácia prípustná? In Kultúra, 1939, roč. 11, č. 5, s. 103-104.

20 Nové slovenské školstvo I. Bratislava: Ministerstvo školstva a národnej osvety, 1940, s. 25-28. 
Živena vyšiel už v marci 1939 rozsiahly článok o perspektívach dievčenského školstva, v ktorom sa konštatovalo, že postupným vyrad'ovaním žien z niektorých povolaní klesne na niektorých odborných a stredných školách počet študentiek. To by znamenalo, že pri postupnom rušení koedukácie by dievčenské školy fungovali len v niektorých väčších mestách. ${ }^{21}$ Prijatím vládneho nariadenia o organizácii a správe strednej školy sa mali vytvorit’ separátne školy pre dievčatá, prípadne samostatné triedy v oddelených častiach budovy. ${ }^{22}$ Dôsledkom bolo zníženie počtu študujúcich dievčat na stredných školách. ${ }^{23}$

Minister Jozef Sivák vo svojom expozé z 22. októbra 1940 o vládnom návrhu zákona, ktorým sa zriad'ovali učitel'ské akadémie, naznačil potrebu obmedzit' prijímanie dievčat na učitel'ské ústavy, ked’že ,učiteliek je viac, než treba “. ${ }^{24}$ Prijatím zákona č. 288/1940 S1. z. z 29. októbra 1940 o učitel'ských akadémiách ${ }^{25}$ sa spustila reforma učitel'ského vzdelávania, ktorej súčast'ou bolo aj zrušenie koedukácie na učitel'ských akadémiách už od školského roka 1939/1940 (od školského roka 1942/1943 mali byt' všetky učitel'ské akadémie bud' chlapčenské, alebo dievčenské). ${ }^{26}$ Povinným predmetom na dievčenských akadémiách sa stalo varenie. ${ }^{27}$ Ciel’om zrušenia koedukácie ako súčasti reformy stredného školstva bolo v konečnom dôsledku zredukovat' počet dievčat na gymnáziách a v učitel'ských ústavoch. ${ }^{28}$ Reforma dievčenského školstva smerovala totiž , $k n a ́$ vratu žien $k$ pôvodnému poslaniu, čiže rodine a domácnosti “ ".99

V rámci diskusií o reformách a reorganizácii stredných škôl sa vo svojom prejave minister školstva Jozef Sivák širšie dotkol otázky vzdelávania žien. Konštatoval, že slovenský národ potrebuje vzdelané ženy, ale ,to neznamená, aby inteligentné ženy slovenské videli svoje životné ambície ukojené len a len po úradoch, kanceláriách, alebo hoci za katedrami “. Reformu stredoškolského vyučovania prepojil s ,reformou životného povolania žien a rodinného života“, preto ideálom dievčat mala byt' stredná škola, ktorá ,,pripravuje na rodinný život. Niet toho diplomu, čo by vyvážil život rodinný! "30 Snahou vlády bolo poskyt-

21 J.Č. Výhl’ady dievčenského školstva u nás. In Živena, 1939, roč. 29, č. 3, s. 76-77.

22 Vládne nariadenie č. 168/1939 zo dňa 11. júla 1939 o organizácii a správe strednej školy §11.

23 KÁZMEROVÁ, ref. 4, s. 32.

24 Nové slovenské školstvo II., ref. 16, s. 10.

25 Pôvodne učitel'ské ústavy, od 1. septembra 1940 učitel'ské akadémie.

26 Nové slovenské školstvo III. Bratislava: Štátne nakladatel'stvo, 1942, s. 38.

27 Tamže, s. 40.

28 Podl'a štatistiky Ministerstva školstva a národnej osvety bolo v školskom roku 1937/1938 na stredných školách a učitel'ských ústavoch 7522 žiačok, z celkového počtu 22802 študentov (t. j. 33,8 \%). V školskom roku 1942/1943 tvorili dievčatá 28,4 \% všetkých študentov stredných škôl a učitel'ských ústavov. Pät' rokov slovenského školstva, ref. 9, s. 214-216.

29 Nové slovenské školstvo II., ref. 16, s. 65.

30 Nové slovenské školstvo I., ref. 20, s. 27. 
nút' dievčatám príležitost', aby upravili svoje vzdelanie smerom „k štastnému rodinnému krbu“.

Reforme dievčenského štúdia na stredných školách bola na ministerstve venovaná vel'ká pozornost'. Vzniklo viacero návrhov na usmernenie stredoškolského vzdelávania dievčat. ${ }^{31}$ Dievčenské školy preto mali mat' dva smery: prvý pre nadanejšie dievčatá, kde popri rodinnej výchove mala byt' aj príprava na vysokoškolské štúdium a druhý smer predpokladal osobitné vzdelávanie, ktoré „potrebuje kultúrna žena v rodine a v spoločnosti “. ${ }^{32}$ Odborné školy pre ženské povolania mali pripravit' ,dievčenský dorast, aby dobre vyhovel požiadavkám, ktoré kladú dnešné časy na ženu v rodine i mimo nej “ a zároveň uplatnit” , všetky svoje schopnosti, prednosti a hodnoty ženskej duše ". ${ }^{33}$ Tomuto ciel'u mala byt' prispôsobená aj výchova a vzdelanie dievčat na osobitných odborných školách pre ženské povolania, ${ }^{34}$ ktoré im zároveň mali umožnit' uplatnit' sa v praktickom zamestnaní (sociálne pracovníčky, vychovávatel'ky, administratívne pracovníč$\mathrm{ky}$, ošetrovatel'ky a diétne pracovníčky $\mathrm{v}$ nemocniciach). ${ }^{35}$ Úlohou odborných škôl pre ženské povolania malo byt' odbremenenie stredných škôl, vyriešenie problému koedukácie a ,nadprodukcie " maturantiek. ${ }^{36}$

Ďalšiu diskusiu o smerovaní stredoškolského štúdia spustil vládny návrh zákona na obmedzenie vysokoškolského štúdia dievčat z 25. júna 1941. V bezprostrednej reakcii priniesol denník Slovák názor, že „po tomto rozhodnutí stratilo stredoškolské štúdium pre dievčatá význam, lebo po jeho absolvovaní nemôzzu ist'v prevažnej miere na vysoké školy " ${ }^{37}$ Predsedníctvo vlády uvažovalo o dvoch návrhoch. Prvý predpokladal vytvorenie 8-triednych vyšších dievčenských škôl ako náhradu za gymnázia. ${ }^{38}$ Tieto školy mali zabezpečovat’ aj ,,prak-

31 V jednom návrhu z roku 1940 sa predpokladalo pre dievčatá len štúdium na meštianskych školách a vyšších stredných dievčenských školách. Až absolvovanie diferenciálnej maturitnej skúšky by im bolo umožnilo pokračovat' na niektorých špeciálnych druhoch vysokoškolského štúdia. Bližšie Pät' rokov slovenského školstva, ref. 9, s. 216-217.

32 Tamže, s. 217-218.

33 Tamže, s. 264.

34 Celkovo bolo týchto škôl 20 (19 slovenských a 1 mad’arská). V školskom roku 1942/1943 na nich študovalo 1567 žiačok. Pät' rokov slovenského školstva, ref. 9, s. 265.

$35 \mathrm{~V}$ učebných osnovách boli praktické predmety: varenie (l'udové, diétne), zdravé bývanie, stolovanie, domáce hospodárstvo, zdravie, starostlivost' o diet’a. Návrhy učebných osnov pre odborné školy pre ženské povolania. Slovenský národný archív, Bratislava (d’alej SNA), fond (d’alej f.) Ministerstva školstva a národnej osvety (d’alej MŠaNO), kartón (d’alej k.) 9, Odborné školy pre ženské povolania, 1941.

36 Nové slovenské školstvo III., ref. 26, s. 54.

37 Stredoškolské štúdium dievčat po obmedzení vysokoškolského štúdia žien. In Slovák, 3. júla 1941, roč. 23, č. 151, s. 3.

38 Osobitné prednášky mali byt' venované estetike, psychológii, dejinám umenia a dejinám filozofie, moderným jazykom. Zachovaná by zostala aj latinčina. 
tické vzdelanie “. ${ }^{39}$ Ked’že prvý návrh bol finančne nákladný, druhý predstavoval jeho šetrnejší variant - zvýšenie úrovne meštianskej školy. Podl'a idealistických očakávaní sa slovenské dievčatá mali vo vel'kom prihlasovat' do odborných škôl pre ženské povolania, do škôl rodinných a sociálnych, ktoré ,,najlepšie vyhovujú ich ženskej povahe “. ${ }^{40}$

V správe z porady o reforme dievčenského stredoškolského štúdia na ministerstve školstva z 21. augusta 1941 sa riešila , reorganizácia dievčenského stredného školstva po obmedzení štúdia dievčat na vysokých školách “. V rámci návrhov odznelo, že výchova a vzdelávanie dievčat na strednej škole mali zohl'adnit' ich „,budúce poslanie matky - vychovávatel'ky“. Aj pri zachovaní všeobecnej náplne vzdelávania sa mal dôraz klást' na špeciálne ,ženské predmety“ (domáce náuky, vychovávatel'stvo, zdravoveda). Všetci prítomní sa jednoznačne vyslovili za zachovanie a neobmedzovanie štúdia dievčat na stredných školách, ale aby sa pri vyučovaní dievčat bral ,praktický zretel' na budúce povolanie ženy. Dievčatá ako budúce manželky, matky a reprezentantky slovenského domova musia byt' vel’mi svedomite pripravené a náležite vzdelané ". ${ }^{41}$ Predpokladalo sa vytvorenie dvoch typov stredných škôl pre dievčatá. Gymnáziá mali umožnit' d’alšie štúdium dievčat na univerzite a vyššie dievčenské školy (štvorročné) mali mat' praktický charakter.

\section{Návrh na obmedzenie vysokoškolského štúdia žien}

Diskusie o d'alšom smerovaní stredoškolského štúdia dievčat sa tak bezprostredne prepojili s pokusom vlády obmedzit' vysokoškolské štúdium dievčat. Na podnet vlády sa 25. júna 1941 zišla špeciálna komisia, na ktorej sa diskutovalo o probléme vysokoškolského štúdia. ${ }^{42}$ Porada bola zvolaná kvôli obavám, že „, $v$ najbližšom čase nastane u nás väčši prebytok vysokoškolsky školených žien a niektoré odbory vysokoškolského štúdia nijak nezodpovedajú ženskej povahe“. Na stretnutí bolo dohodnuté predložit' vláde návrh, podl'a ktorého by sa upravovalo vysokoškolské štúdium žien už od 1. septembra 1941. Ministerstvo školstva a národnej osvety následne 28. júna 1941 rozoslalo Osnovu vládneho nariadenia o dočasnej úprave štúdia žien na Slovenskej univerzite, aby získalo pripomienky

39 Strojopis, spoločenská výchova, rýchlopis, hudba, varenie, šitie, tovaroznalectvo, domáce účtovníctvo a obchodná korešpondencia.

40 Stredoškolské štúdium dievčat, ref. 37, s. 3.

41 A. Anketa o dievčenskom strednom školstve. In Sbornik profesorov Slovákov, školský rok 1941/1942, roč. 21, č. 2, s. 45.

42 Na porade sa zúčastnili zástupcovia ministerstva školstva a národnej osvety, zástupcovia zdravotného odboru ministerstva vnútra, zástupcovia HSL'S a ženy reprezentovala predsedníčka Ženského odboru HSLS Božena Tuková. Obmedzenie štúdia žien na vysokých školách. In Slovák, 28. júna 1941, roč. 23, č. 147, s. 3. 
odbornej verejnosti pre prerokovávanie návrhu zákona na pôde snemu ${ }^{43}$ Podla $\S 1$ vládneho návrhu sa mal obmedzit’ počet študujúcich žien na Slovenskej univerzite počnúc študijným rokom 1941/1942 v jednotlivých študijných ročníkoch - na lekárskej fakulte na 50, na filozofickej fakulte na 30 a na prírodovedeckej fakulte na 15 študentiek. Na právnickej fakulte nemali ženy študovat' vôbec. Pre nasledujúce akademické roky malo ministerstvo školstva a národnej osvety upravit' počet študentiek podl'a potreby. Podl'a $\S 2$ malo ministerstvo určit' aj smernice na výber dievčat pre štúdium. Zapísaným študentkám sa malo umožnit' štúdium dokončit'. Návrh zákona sa nemal dotknút' štúdia žien na Slovenskej vysokej škole technickej ${ }^{44}$ a Vysokej obchodnej škole. ${ }^{45} \mathrm{~V}$ dôvodovej správe k návrhu zákona jeho autori argumentovali snahou vrátit' slovenskú ženu rodine. Odvolávali sa pritom na sociálnu politiku štátu. Poskytovanie príspevkov na manželku bez zamestnania v prípade ženatých štátnych zamestnancov a odchodného pre prepustené vydaté štátne zamestnankyne malo za ciel' ,, vrátit'ženu k rodinnému povolaniu " a zároveň umožnilo mnohým slobodným zamestnancom založit' si rodinu. Pri pohl'ade do budúcnosti chcela vláda ,,siahnut' $k$ preventívnym opatreniam ", a to v prvom rade k úprave štúdia žien na vysokých školách, aby sa v najbližších rokoch nedostavil nežiaduci nadbytok vysokoškolsky vzdelaných žien. Podl'a dôvodovej správy ženy, ktoré ukončili vysokoškolské štúdium, hl'adali svoje uplatnenie len v štátnych a verejných službách, napríklad ako profesorky na stredných školách a učitel'ských akadémiách, lekárky v štátnych zdravotných ústavoch a právničky v sudcovských službách. Vysokoškolsky vzdelané ženy mali už v blízkej budúcnosti narazit' na silnú konkurenciu mužského vysokoškolského dorastu. Predložený návrh zákona mal preto predíst' vysokej nezamestnanosti vysokoškolsky vzdelaných absolventov úpravou, lepšie povedané obmedzením vysokoškolského štúdia žien. V dôvodovej správe boli použité aj štatistické podklady o počtoch riadnych poslucháčok na jednotlivých fakultách Slovenskej univerzity (v akademickom roku 1940/1941 študovalo na právnickej fakulte 736 mužov a 37 žien, na lekárskej fakulte 624 mužov a 100

43 Osnova vládneho nariadenia o dočasnej úprave štúdia žien na Slovenskej univerzite. SNA, f. Snem Slovenskej republiky (d’alej SSR), k. 128, signatúra II - 6a/1 - 475, j. č. 1390.

44 Vysoká škola technická Dr. Milana Rastislava Štefánika vznikla na základe zákona č. 170 Sb. z. a n. z 25. júna 1937 v Košiciach, odkial' bola po arbitrážnom rozhodnutí prest'ahovaná najskôr do Prešova a začiatkom decembra 1938 do Turčianskeho Sv. Martina. Nakoniec sa slovenská vláda rozhodla technickú vysokú školu prest'ahovat' do hlavného mesta (kvôli nedostatku vhodných priestorov a pedagógov). Na základe zákona č. 188/1939 zo dňa 25. júla 1939 bola v Bratislave zriadená Slovenská vysoká škola technická. Pät’ rokov slovenského školstva, ref. 9, s. 284-292.

45 Na základe žiadosti obchodných a priemyselných kruhov bola nariadením s mocou zákona č. 248/1940 S1. z. zo dňa 4. októbra 1940 zriadená Vysoká obchodná škola s právom verejnosti. Pät' rokov slovenského školstva, ref. 9, s. 296-297. 
žien, na filozofickej fakulte 406 mužov a 208 žien, na prírodovedeckej fakulte 180 mužov a 77 žien). Kvôli nedostatku lekárov sa malo najmenej obmedzovat' štúdium žien na lekárskej fakulte. Na filozofickej a prírodovedeckej fakulte mala byt' možnost' štúdia žien obmedzená, aby sa kompenzoval úbytok v stave profesoriek na stredných školách a na učitel’ských akadémiách. Zo štúdia práva mali byt' ženy vylúčené úplne, nakol'ko ,študovat' právo neodôvodňuje nijaká zretel'u hodná okolnost'“. Pri stanovení podmienok prijatia žien chcelo ministerstvo „pripustit’ najkvalitnejšie uchádzačky“. Návrh počítal aj s d’alšou úpravou (znižovaním, zvyšovaním počtu žien na vysokých školách). ${ }^{46}$

Dôvody, ktoré viedli k vypracovaniu návrhu, boli v podstate dva: ,,aby slovenská žena čím skôr bola prinavrátená svojmu prvotnému povolaniu, rodine", a zároveň „aby sa neprodukoval taký počet vyštudovaných žien na vysokej ško$l e$ ". ${ }^{47}$ Štúdium dievčat sa malo preorientovat' na sociálnu oblast”.

V júli 1941 ministerstvo školstva a národnej osvety zaslalo na Rektorát Slovenskej univerzity požiadavku na zistenie presného počtu zapísaných študentiek a študentiek, ktoré ukončili štúdium na právnickej, lekárskej a filozofickej fakulte Slovenskej univerzity v rokoch $1929-1938^{48}$ a Osnovu vládneho nariadenia o dočasnej úprave štúdia žien na Slovenskej univerzite. ${ }^{49}$

Dňa 21. júla 1941 Rektorát Slovenskej univerzity informoval ministerstvo školstva a národnej osvety o pripomienkach dekanov a profesorských zborov jednotlivých fakúlt Slovenskej univerzity. V Archíve Univerzity Komenského sa zachovala len reakcia Dekanátu Prírodovedeckej fakulty Slovenskej univerzity, ${ }^{50} \mathrm{v}$ ktorej dekan prof. František Valentin uviedol, že nesúhlasí so zavedením „,numerus clauzus pre ženy, t. j. ktorá žena študovat' chce, nech študuje, ked’že univerzitné štúdium v Slovenskej republike je slobodné a myslím, že aj ústava Slovenskej republiky obsahuje túto zásadu. I ked' žena nejde učit’ na strednú školu po absolvovani univerzitného štúdia, má to svoj klad v tom, že sa úroven̆ všeobecného vzdelania žien zvyšuje, notabene, ked'sa žena vydá, má ako akademicky vzdelaná určitý vyšší, jadrnejši a kvalitnejši postoj k výchove rodiny, čo je

46 SNA, f. SSR, k. 128, signatúra II - 6a/1 - 475, j. č. 1390.

47 Obmedzenie štúdia žien na vysokých školách. In Slovák, 28. júna 1941, roč. 23, č. 147, s. 3.

48 Výkazy bolo potrebné vyhotovit' podl'a fakúlt a podl'a jednotlivých študijných rokov. Dočasná úprava štúdia žien na Slovenskej univerzite. Archív Univerzity Komenského, Bratislava (d’alej AUK), f. Rektorát Univerzity Komenského (d’alej RUK) I, k. 52, j. č. A - 10/1 (1940 - 1950), 35.913/41-III.

49 Osnova: Vládne nariadenie o dočasnej úprave štúdia žien na Slovenskej univerzite. Dočasná úprava štúdia žien na Slovenskej univerzite. AUK, f. Rektorát Univerzity Komenského I, k. 52, j. č. 3153/40-41.

50 Dekanstvo Prírodovedeckej fakulty Slovenskej univerzity. Osnova vládneho nariadenia o dočasnej úprave štúdia žien na Slovenskej univerzite, pripomienky dekana Prírodovedeckej fakulty. AUK, f. RUK I, k. 52, Č. 1389/40 - 41, 8. júla 1941. 
u nás malého národa, vel'mi žiaduce, pravda je nutné pri tom sa postarat' hlavne aj o to, aby sa mohli manželstvá v širšom rámci uzatvárat' a potom by sa mohlo premýšl'at'o širšom vylúčení žien z univerzitného štúdia a nie obrátene ako sa to pripravuje“. Navrhol preto úpravu, písomné vyhlásenie, že žena nastupuje na štúdium ,čiste pre zvýšenie úrovne svojho osobného vzdelania chce Slovenskú univerzitu navštevovat' a nie preto, aby zabrala dáke miesto vo verejnom živote, ktoré patrí mužovi, opakujem: tej žene nech sa umožní v plnom rozsahu štúdium na fakultách ". ${ }^{1}$

Návrh vládneho nariadenia o dočasnej úprave štúdia žien na Slovenskej univerzite vyvolal skutočne búrlivé diskusie medzi odbornou verejnost'ou a aj na stránkach tlače. Už 22. júla 1941 poskytol odborné stanovisko Spolok profesorov Slovákov (SPS) na rokovaní špeciálnej komisie, ktorej členkami boli aj dve profesorky - Viktória Horňáková a Mária Tilkovská. Stanovisko SPS bolo zaslané ministerstvu školstva a národnej osvety 12. augusta 1941. Ako sa uvádzalo v správe Spolku profesorov Slovákov, ciel’om vládneho návrhu bolo ,, vrátit ženu rodine ". Komisia preto diskutovala o probléme vysokoškolského vzdelávania žien komplexne, z pohl'adu kultúrneho, stavovského, sociálneho a spoločenského. V stanovisku sa pripúšt’alo, že na Slovensku je vel’a žien v štátnych a verejných službách, ktoré by mohli , lepšie plnit’ svoje životné poslanie vúzkom kruhu rodinnom a ktoré by, venujúc sa len vedeniu domácnosti a výchove dietok, boli omnoho užitočnejšími členmi nášho národa a občiankami nášho štátu " ${ }^{52}$ Zároveň ale vo svojom stanovisku uviedli, že , vylučovat' ženy z možnosti vzdelávat' sa znamenalo by degenerovat' ich na akýchsi menejcenných tvorov, podceňovat' ich doterajšiu prácu “. Obmedzenie prístupu žien na Slovenskú univerzitu je podla stanoviska SPS „obmedzením práva na vyššie vzdelanie, ktoré má každý občan štátu ". ${ }^{53}$ Komisia d'alej uviedla, že pre Slovensko nemohol byt' nadbytok vzdelaných žien neštastím, práve naopak bol „,v tom zdravý a potrebný pokrok slovenského národa". V stanovisku sa konštatovalo, že inteligentnejšie a vzdelanejšie ženy sú aj lepšími matkami, ktoré môžu vychovat’ vzdelanejšie a lepšie vychované deti. ${ }^{54}$ Numerus clausus pre ženy by podl'a stanoviska komisie SPS bol výnimočným opatrením, ktoré sa nikde vo svete neobjavilo. ${ }^{55}$ Spolok profesorov

51 V archíve Univerzity Komenského sa zachovalo len stanovisko dekana Prírodovedeckej fakulty. Osnova vládneho nariadenia o dočasnej úprave štúdia žien na Slovenskej univerzite, pripomienky dekana Prírodovedeckej fakulty, 8. júla 1941. AUK, f. RUK I, k. 52, j. č. $1389 / 40-41$.

52 Stanovisko SPS k návrhu vl. nariadenia o dočasnej úprave štúdia žien na Slovenskej univerzite. In Sbornik Spolku profesorov Slovákov, školský rok 1941/1942, roč. 21, č. 1, s. 14-18.

53 Tamže, s. 14.

54 Tamže, s. 15.

55 V stanovisku sa spomína aj situácia v susedných a „spriatelených“ štátoch, kde bolo obmedzené štúdium žien len na právnických fakultách (Mad’arsko) alebo na vykonávanie advokácie 
Slovákov upozorňoval, že v dôsledku prijatia návrhu na obmedzenie štúdia žien na vysokých školách by klesol aj počet dievčat na stredných školách. V správe sa uvádzali mnohé dôvody, pre ktoré je potrebné umožnit’ ženám vzdelávat' sa na filozofickej, právnickej i lekárskej fakulte. Štúdium jazykov, práva a najmä medicíny vyhovuje podl'a stanoviska ženskej povahe. Obmedzenie vzdelávania by sa premietlo aj do st'aženia spoločenského uplatnenia žien (,,žena by stratila možnost' uplatnit'sa ako rovnocenná zložka "56). Pre mnohé chudobné dievčatá bolo vysokoškolské vzdelanie jediným venom, ktoré si odnášali do manželstva. V stanovisku SPS sa hovorí aj o nie vel'mi vhodnom časovom rámci na riešenie otázky vysokoškolského vzdelávania žien. Vojnové obdobie totiž môže spôsobit' „medzery v radoch vysokoškolsky vzdelaných mužov", ktoré by mohli vhodne zaplnit' práve ženy. Absolvovanie vysokoškolského štúdia navyše nikoho neoprávňovalo na prijatie do štátnej alebo verejnej služby. V závere navrhol Spolok profesorov Slovákov , pripustit’ ženský dorast na každú fakultu Slovenskej univerzity bez obmedzenia s tým, že absolvovanie vysokej školy nedáva ženám nárok na umiestnenie $v$ štátnych, alebo verejných službách ". ${ }^{57}$ Regulácia vysokoškolského štúdia sa tak mala dosiahnut' nenásilne, regulovaním zamestnávania žien vo verejnej a štátnej službe. V správe sa jednoznačne konštatovalo, že „,vzdelanie je duchovná hodnota, ktorú nemožno nikomu odopriet' a tým menej vziat" ".58

Naopak, podporné stanovisko k vládnemu návrhu uverejnila Slovenská pravda. Neznámy autor (Er) vyšiel pri formulovaní svojho názoru k obmedzeniu štúdia dievčat na vysokých školách z predpokladu, že ,,prirodzené miesto dievčat’a je v rodine, a že ani doterajšie stredoškolské a tým menej vysokoškolské štúdium ho na toto poslanie nepripravuje“. Podla jeho názoru slovenská spoločnost' potrebovala najmä ,zdravé, pre život a jeho tažkosti dobre pripravené ženy - matky, ktoré sa nebudú bát' rodiny a t’ažkostí, ktoré sú s rodinným životom a s výchovou detí spojené “. ${ }^{9} \mathrm{~V}$ článku opätovne argumentoval „prirodzeným poslaním ženy“, ktoré bolo „určené samým Stvoritel'om v rodine“. Autor pripustil, že vysokoškolské vzdelanie malo určité prednosti, ale tie boli skôr ,,rázu

a súdnictva (Taliansko). V prípade Mad’arska sa spomína aj obmedzenie štúdia žien na inžinierskych odboroch vysokých technických škôl. V stanovisku sa ale nespomína príklad nacistického Nemecka, kde v decembri 1933 bolo zavedené reštriktívne nariadenie o obmedzení vysokoškolského štúdia. Podl'a nariadenia malo nastúpit’ na univerzity a vysoké školy 15000 nových študentov, pre každú krajinu boli stanovené presné kvóty. Počet nových študentiek potom nesmel prekročit' $10 \%$ z kvóty pre jednotlivé krajiny. Tieto reštriktívne opatrenia sa ale v praxi neosvedčili. STEPHENSON, ref. 6, s. 133-134.

56 Stanovisko SPS, ref. 52, s. 16.

57 Tamže, s. 17.

58 Tamže, s. 18.

59 ER. Čo je s vysokoškolským štúdiom dievčat. In Slovenská pravda, 30. septembra 1941, roč. 6 , č. 224 , s. 1 . 
individuálneho "a platili len pre jednotlivé dievčatá a nie pre celok. V niektorých odboroch sa vysokoškolsky vzdelané ženy uplatňovali lepšie ako muži (napríklad v detskom a ženskom lekárstve), ale „nesmieme zabúdat', že vysokoškolské štúdium vo všeobecnosti odsudzuje dievčatá domovu a povolaniu ženy-matky“. Vysokoškolsky vzdelané ženy podl'a neho ,tratia zmysel pre domácnost', v ktorej i tak prv-neskôr zakotvia. A ked' raz založia rodinu, už je t'ažko myslitelné, aby sa bez škody rodiny venovali zamestnaniu, na ktoré sa štúdiom pripravili. Tak sa stáva, že nie sú ani v povolaní činné, a ani v rodine sa nevedia dostatočne uplatnit', a aspoň za istý čas sú v nej bezradné “. V domácnosti a v rodine sa údajne lepšie osvedčili dievčatá so stredoškolským (respektíve so stredoškolským odborným vzdelaním). Následne teda neznámy autor položil otázku, načo by bolo dievčatám to vysokoškolské štúdium. Dievčatá dosiahli síce vyššiu intelektuálnu a spoločenskú úroveň, ktorá ale bola príliš draho vykúpená. V závere tento autor alibisticky zhrnul svoj postoj k vysokoškolskému štúdiu dievčat, že „sme len proti takému vysokoškolskému štúdiu dievčat, ktoré odcudzuje ženu od jej Bohom určeného poslania, to jest poslania ženy - matky - (predovšetkým vlastných detí!), a tu musime bohužial konštatovat', že okrem nepatrných výnimiek je takým celé naše vysokoškolské štúdium, a teda že sa pre naše slovenské devy nehodi" ". ${ }^{0}$

Právne stanovisko k návrhu na obmedzenie štúdia žien na vysokých školách priniesol časopis Verejné právo. Súčast'ou článku je podrobná právna analýza problému obmedzovania vysokoškolského štúdia žien. Autor Tibor Galbavý argumentoval, že neexistuje právny podklad, ktorý by výslovne obmedzoval (prípadne úplne zakazoval) návštevu vysokých škôl ,z titulu pohlavného diferencovania poslucháčov “. ${ }^{11}$ Po objasnení právnej situácie autor prešiel k ,podstate problému “. Diskusia o obmedzovaní vysokoškolského štúdia žien podl'a neho odrážala „problém školskej a kultúrnej politiky“. Podl'a Galbavého hlavným argumentom proti návrhu na obmedzenie štúdia žien bolo nízke percento všetkých vysokoškolsky sa vzdelávajúcich žien, než aby ,,mohlo mat’ vážny vplyv na ich odpútanie od svojho prvotného povolania ako ženy - matky".${ }^{62}$ Autor pripustil, že ženy sa do istej miery stránia svojho prvotného povolania, ale považuje to za jav všeobecný, ktorého príčiny nie sú vo vzdelávaní žien, ale v uvol’není mravov, sekulárnej zmene názorov na niektoré mravné, sociálne a spoločenské vzt'ahy. Od materstva sa ,odtahujú “ nielen vysokoškolsky vzdelané ženy, ale aj ženy bez akéhokol'vek zvláštneho vzdelania (poukazuje na remeselnícke, robotnícke a úradnícke rodiny bez diet’at'a alebo len s jedným diet’at’om). Druhým argumen-

\footnotetext{
60 Tamže.

61 GALBAVÝ, Tibor. K otázke vysokoškolského štúdia žien. In Verejné právo, 1941, roč. 2, č. 8, s. 249-255.

62 Tamže, s. 252.
} 
tom proti obmedzeniu bol malý „,príliv žien na univerzitu“, takže sa „,nemusíme obávat prebytku, ktorý by sa u nás nemohol umiestnit' (naopak so vznikom Slovenského štátu ženy obsadili uvol'nené pozície, na ktoré nebolo dostatok mužov) “. Autorovi sa ale nepozdávalo, že sa žena dostala aj na ,sudcovský stolec, čo im skutočne akosi nepristáva “. Pripustil ale, že by žena mohla súdit’ spory svojich spoluobčaniek. Vo svojej analýze poukázal na zaujímavý fakt, že nie všetky zapísané študentky školu aj dokončia a ,tie, ktoré to vydržia do konca, tvoria skutočne elitu a za svoju vytrvalost' a námahu si svoju akademickú hodnost' aj zaslúžia".

K d'alším argumentom patril sociálny rozmer celého problému (zákaz štúdia žien na vysokých školách by mohol byt' považovaný menej majetnými vrstvami obyvatel'stva za nesociálne opatrenie, lebo nemajetné by nemohli študovat' vôbec, majetné by študovali v zahraničí) a medzinárodný rozmer, pretože okolité národy nelimitujú vzdelávanie žien (napr. Mad'arsko) a obmedzenie štúdia žien by sa vzt’ahovalo aj na cudzinky, čo by nebolo dobrou propagáciou Slovenska a slovenskej vedy. Autor pripustil riešenie celého problému kompromisom. Niektoré povolania ,ako napr. právo nevyhovujú ženskej povahe“, preto v tomto prípade považoval za rozumné zaviest' istý numerus clausus. ${ }^{63} \mathrm{Všeobecný} \mathrm{zákaz}$ štúdia ale považoval za nevhodný.

Pôvodný návrh vládneho nariadenia o dočasnej úprave vysokoškolského štúdia dievčat bol na ministerstve školstva len minimálne upravený. ${ }^{64}$ Odmietavé odborné stanoviská (právne, sociálne aj pedagogické) a ostrá polemika s jednoznačne odmietavými argumentmi samotných žien viedli ministra školstva k stiahnutiu tohto návrhu. ${ }^{65}$ Minister školstva a národnej osvety Jozef Sivák informoval 26. augusta 1941 predsedu vlády, že ,,vzhl'adom na všeobecný odpor podráždenej verejnosti, ktorý je čím d'alej silnejší, proti osnove vládneho nariadenia o úprave štúdia žien na Slovenskej univerzite" návrh nebol daný na program ministerskej rady. Minister zároveň odporučil predbežné odloženie tohto návrhu. ${ }^{66}$

Minister školstva Jozef Sivák sa ale svojho návrhu nemienil vzdat’ bez boja. Aj v decembri 1941 vo svojom expozé argumentoval vysokým podielom študentiek na vysokých školách. Uviedol, že na Slovenskej univerzite k decembru 1941 študovalo 453 študentiek riadneho štúdia (z 2468 študentov) a na Slovenskej

63 Tibor Galbavý navrhoval pomer 9:1, teda na 100 poslucháčov by pripadlo 10 žien. GALBAVÝ, ref. 61, s. 255.

64 V prípade právnickej fakulty upravený návrh predpokladal mimoriadne štúdium žien na tejto fakulte. Vládne nariadenie o dočasnej úprave štúdia žien na Slovenskej univerzite. SNA, f. Úrad predsedníctva vlády (d'alej ÚPV), k. 164, č. 101 - 2 A - 019, j. č. 11051.

65 Tamže.

66 Tamže. 
vysokej škole technickej 38 študentiek riadneho štúdia. ${ }^{67}$ Podl’a podrobnejších štatistických podkladov v období akademických rokov 1938/1939 - 1942/43 dovedna študovalo na vysokých školách 2773 poslucháčok (z celkového počtu 18849 poslucháčov) - teda $14 \%$, na stredných školách študovalo z celkového počtu žiactva $30 \%$ žiačok. To znamená, že po ukončení stredoškolského štúdia dievčatá zväčša nepokračovali v štúdiu na vysokej škole. ${ }^{68}$ Na Slovenskej univerzite $\mathrm{v}$ tomto období z celkového počtu 12753 poslucháčov študovalo 2501 žien (zaokrúhlene $20 \%$ ), na Slovenskej vysokej škole technickej zo 4306 poslucháčov bolo 172 žien (4 \%), na Vysokej obchodnej škole z 1322 zapísaných bolo 98 žien (7,4\%). Spomedzi fakúlt Slovenskej univerzity najviac poslucháčok študovalo na filozofickej fakulte ( $33 \%$ ), na prírodovedeckej tvorili ženy $32 \%$ študentov a pokles nastal len na právnickej fakulte. ${ }^{69}$

V marci 1942 bol vládny návrh na obmedzenie vysokoškolského štúdia žien definitívne odložený. ${ }^{70}$

Podl'a štatistických údajov mal počet študujúcich žien v rokoch 1939 - 1944 stúpajúcu tendenciu. V akademickom roku 1939/1940 sa na univerzitu zapísalo 373 žien, v nasledujúcom akademickom roku 478 študentiek. V akademickom roku 1941/1942 sa zapísalo už 536 žien, o rok neskôr bolo zapísaných 799 poslucháčok, ktoré tvorili celkovo 22,7 \% študujúcich na Slovenskej univerzite. V akademickom roku 1943/1944 sa na všetky fakulty Slovenskej univerzity zapísalo celkovo 928 poslucháčok.

V poslednom roku vojnovej Slovenskej republiky počet študujúcich žien klesol. ${ }^{71}$ Celkovo však počet študujúcich žien v rokoch 1939 - 1944 postupne rástol. Vládne nariadenie o obmedzení štúdia dievčat sa nepodarilo presadit'. K jeho obmedzovaniu ale dochádzalo najmä v dôsledku sociálnej a politickej situácie v krajine. Vysokoškolské štúdium dievčat bolo nad'alej komplikované najmä nedoriešenými ubytovacími kapacitami pre študentky. ${ }^{72}$ Jediný internát, ktorý mali študujúce dievčatá k dispozícii (Dievčenský univerzitný internát) mal nedostatočnú kapacitu. Začiatkom akademického roka 1942/1943 vznikol vysokoškolský internát pre vodkyne Hlinkovej mládeže Tatranka, ale ešte nebol zariadený. Mohol ubytovat' 80 dievčat v 11 jednopostel'ových, 18 dvojpostel'ových a 11 troj-

67 Nové slovenské školstvo III., ref. 26, s. 60-61. Podrobná štatistika zapísaných študentov a študentiek bližšie Pät' rokov slovenského školstva, ref. 9, s. 311-317.

68 Tamže, s. 324.

69 Tamže, s. 324-325.

70 Vládne nariadenie o dočasnej úprave štúdia žien na Slovenskej univerzite. SNA, fond ÚPV, k. 164, č. $101-2$ A - 019, j. č. 11051.

71 DOLAN - BARTL, ref. 11, s. 27; ŠEMŠEJ, Matej. Univerzitné študentky počas prvej Slovenskej republiky. In DUDEKOVÁ, Gabriela a kol. Na ceste k modernej žene: Kapitoly z dejín rodových vztahov na Slovensku. Bratislava: Veda, 2011, s. 367-368. ISBN 9788022411899.

Bližšie o sociálnych problémoch študentiek ŠEMŠEJ, ref. 71, s. 370-374. 
postel’ových izbách. ${ }^{73} \mathrm{Na}$ jeseň 1944 sa frontová línia priblížila k hraniciam Slovenska a otázka ženského vzdelávania bola prekrytá inými existenčnými problémami.

\section{Vzdelávanie dievčat pohl'adom slovenských žien}

Vel'kú pozornost' venovali vzdelávaniu dievčat najmä ženské časopisy. V Trnave vychádzala Nová žena, ktorá oslovovala prevažne vzdelané ženy - katoličky, ktoré sa angažovali vo verejnom živote, odmietali názory o menejcennosti žien a v mnohých prípadoch pripomienkovali oficiálnu politiku vládnucej l'udáckej elity. ${ }^{74}$ Ženský časopis Živena, ktorý sa tradične zaoberal najmä literatúrou a umeleckým životom, sa tiež zapájal do verejných diskusií k ženským problémom. Na stránkach ženských časopisov vychádzali články k mnohým aktuálnym témam. Pravdepodobne najdiskutovanejšou bola práve otázka vzdelávania dievčat a žien. Okrem všeobecných príspevkov o potrebe vzdelávania slovenských žien sa diskusia preniesla do roviny konkrétnych reakcií na niektoré opatrenia štátnej moci. Prispievatel'ky reagovali na zrušenie koedukácie, reformu dievčenského stredoškolského štúdia a na otázku obmedzenia vysokoškolského štúdia dievčat.

Všeobecne koncipované príspevky zdôrazňovali najmä význam vzdelávania pre profesijný aj súkromný život žien - sebadôveru, sebaúctu, schopnost' rovnocenného spolunažívania s mužom, schopnost' správnej výchovy detí. Profesorka Marta Miklošková ${ }^{75}$ sa vo svojom príspevku Výchova našich dievčat postavila proti obmedzeniu štúdia dievčat: ,,Vychovat’ ženu pre manželstvo a materstvo neznamená vziat' ju v štrnástom roku zo školy a dat' jej tzv. praktické všeobecné vzdelania, pod ktorým sa obyčajne myslí - vediet' predovšetkým varit', šit' a diet'a opatrovat', čiže riadit' sa heslom - žene patrí varecha. " Z vlastnej skúsenosti poukazovala na bystrost', snaživost' a pohotovost' dievčat, ktoré sama učila. Preto navrhovala, nech ,,bystré a nadané dievča študuje do svojho osemnásteho roku a potom, ak chce, za rok, nauči sa všetkým domácim prácam “. Marta Miklošková podporila mladé ženy, ktoré chceli študovat' na univerzite. Odmietla názory, že vzdelané ženy „sú stratené“ pre manželstvo a materstvo: „Poznám mnoho

73 Pät’ rokov slovenského školstva, ref. 9, s. 348.

74 Mnohé prispievatel'ky a redaktorky boli manželkami alebo dcérami významných reprezentantov dobovej politickej a spoločenskej elity. Bližšie ZAVACKÁ, Marína. „Nová žena“ so starou prachovkou: Prejavy občianskeho vzdoru na stránkach časopisu Katolíckej Jednoty žien 1939 a 1940. In DUDEKOVÁ, Gabriela a kol. Na ceste k modernej žene: Kapitoly z dejín rodových vztahov na Slovensku. Bratislava: Veda, 2011, s. 376-378. ISBN 9788022411899.

75 Marta Miklošková (* 1912 - † 1966) - učitel'ka, publicistka, aktívna v podpore katolíckej cirkvi aj po roku 1948. Aktívne pôsobila ako učitel'ka ešte v roku 1942, pričom prvé diet’a sa jej narodilo v marci 1939, druhé začiatkom roku 1940. MIKLOŠKO, Jozef. Ako sme boli mali - odtajnené po 60 rokoch. Bratislava: DACO, 2007, s. 116. ISBN 9788096729883. 
žien s akademickým titulom, ktoré žijú v tom najšt’astnejšom manželstve. A dovol'ujem si tvrdit', že tieto ženy sú i dobré matky. "Autorka obraňovala vzdelávanie dievčat: „Štúdium, chápané vážne a opravdive, je nám najlepšou zárukou dobrých žien a matiek. " $76 \mathrm{~V}$ pokračovaní svojho príspevku Marta Miklošková vyslovila potrebu vychovávat' slovenské dievčatá tak, aby boli „múdre, sebavedomé $v$ svojom okoli, a to sebavedomie nesmie stratit' ani v manželstve ". ${ }^{77}$

K otázke vzdelávania žien sa na stránkach Novej ženy vyjadrila vo svojom článku o ženskej osvetovej práci aj redaktorka Helena Sabolová. Autorka na jednej strane vyjadrila súhlas $\mathrm{s}$ návratom žien $\mathrm{k}$ rodinnému kozubu, zároveň ale dodáva, že , aj v rodine treba, aby naša slovenská žena mala z čoho rozdávat"“. Len vzdelaná žena totiž mohla zabezpečit' aj vzdelanie pre svoje deti: ,, Ona vychováva. Ona vštepuje do svojho dietata zásady, ktoré budú utvárat'v d'alšom veku samostatného myslenia nový charakter. Aký široký bude jej horizont, taký siroký bude horizont vedomosti aj u jej detí. "78

Neustále prezentované snahy prepúšt’at' ženy najmä z učitel'ských postov, a tým motivované návrhy na obmedzovanie štúdia dievčat aj na učitel'ských ústavoch vyvolali reakciu dotknutých žien. Na rozhlasovú prednášku o štúdiu dievčat reagovali študentky ,,učiteláčky“ (budúce učitel'ky). Súhlasili s vymedzením úlohy ženy „, byt’ dobrou gazdinkou a matkou, ktorá starostlivo vychováva svoje deti “ aj s obmedzovaním zamestnávania učiteliek, ale argumentovali inými zamestnanými ženami, ktoré stále ešte mohli vykonávat’ svoje povolanie. Študentky považovali práve učitel'ské povolanie za ženám najbližšie: ,, ved' kto iný lepšie pochopí útlu detskú dušu, ked’ nie jemná duša ženy! " Dievčatá študovali na učitel'ských ústavoch nielen kvôli „,chlebu v ruke“, ale najmä z lásky k povolaniu. Aj po vydaji a zanechaní práce vzdelaná žena - učitel'ka mohla uplatňovat' svoje vedomosti vo výchove vlastných detí. Autorky odmietli názory z rozhlasovej prednášky, ,že by medzi ženami s doktorským diplomom neboli stvorenia milé a jemné, že každá vysokoškoláčka musí mat’v sebe čosi mužského a chladného “. Autorky jednoznačne obhajovali štúdium dievčat na učitel'ských ústavoch a súhlasili aj s reformami vo vzdelávaní dievčat, napr. zavedením ,,kuchárskych a šijacích kurzov ", aby sa neskoršie mohli vyštudované učitel'ky realizovat' aj v rodine a domácnosti. ${ }^{79}$

76 MIKLOŠKOVÁ, Marta. Výchova našich dievčat. In Nová žena, 26. februára 1939, roč. 2, č. 9, s. 4.

77 MIKLOŠKOVÁ, Marta. Výchova našich dievčat. In Nová žena, 5. marca 1939, roč. 2, č. 10, s. 9.

78 SABOLOVÁ, Helena. S osvetou medzi najširšie vrstvy. In Nová žena, 5. marca 1939, roč. 2, č. 10, s. 2 .

79 B.G. - A.S. Učiteláčky. Naša pošta: Odpovedáme! In Nová žena, 28. januára 1940, roč. 3, č. 5, s. 11-12. 
Vel'kú pozornost' a pobúrenie vyvolal na stránkach ženských časopisov najmä spomínaný vládny návrh na obmedzenie vysokoškolského štúdia žien v lete 1941. Okrem odbornej verejnosti museli stanovisko zaujat' aj slovenské ženy, najmä vzdelané a verejne aktívne. Živena priniesla rozsiahly materiál na tému vysokoškolského štúdia žien aj s reakciami vysokoškolsky vzdelaných a úspešných žien. Autorka Zora Jesenská reagovala na návrh regulovat' vysokoškolské štúdium žien odvolávkou na názory Eleny Maróthy-Šoltésovej, ktorá sa takmer pred pol storočím jednoznačne vyslovila $\mathrm{v}$ prospech vzdelávania žien. Zora Jesenská v článku odpovedala najmä na príspevok uverejnený v Slovenskej pravde, v ktorom autor schval'oval obmedzenie až úplné vylúčenie žien z vysokých škôl. Redaktorka Živeny sa pustila do polemiky s takýmito názormi v redakcii Slovenskej pravdy. Označila za nezmysel tvrdit', že Slovensko nepotrebuje vzdelaných l'udí, a teda aj vzdelané ženy. Odmietala názor, že vzdelávanie a štúdium žien ohrozuje duševné zdravie národa, akoby vzdelaní l’udia boli nemravnejší ako nevzdelaní (či menej vzdelaní): , Vel'ké vedomosti ženských nemôžu duchovnému zdraviu národa škodit', len osožit' " Poukázala na príklady mimoriadne nadaných žien vo vede a v kultúre, ktoré sa dobrovol’ne zriekli rodinného života. ${ }^{80}$

Živena zároveň uverejnila aj názory vysokoškolsky vzdelaných a zamestnaných žien k téme vysokoškolského štúdia. ${ }^{81} \mathrm{~V}$ prvej reakcii lekárka Edita Ottlyková-Kohútová jednoznačne zdôraznila, že vzdelanie nemení ,náhl'ady ženskej na rodinu, na manželstvo; a ak, nuž v takom smere, že je jej premena prospešná i pre n̆u, i pre jej budúcu rodinu“. V súvislosti s výchovou vyzdvihla význam vzdelávania žien, lebo celá zodpovednost’ za výchovu ležala práve na pleciach matky. Poukázala zároveň na ženské povolania, v ktorých žena (či matka alebo nie) „svojou ženskou dušou ako profesorka, ako lekárka skôr pochopi matku školského, alebo chorého diet'at'a, má viacej pochopenia, viacej trpezlivosti na jej vypočutie a často si povšimne dôležité podrobnosti, ktoré by mužský nezbadal “. Autorka na príklade vlastnej rodiny ukázala dôležitost' a význam vzdelávania žien, ked’že jej dcéra pokračovala v rodinnej tradícii štúdiom medicíny. ${ }^{82}$

Druhá autorka, tiež lekárka, vnímala vysokoškolské vzdelávanie žien ako „, dôsledok premien, ktoré l’udstvo prě̌iva“. Nesúhlasila s názormi, že vzdelané a pracujúce ženy odmietali rodinný život a že vzdelané ženy sa ,odcudzujú svojmu prirodzenému poslaniu a štúdiom stávajú sa menej ženskými “. Vyzdvihla aj vel'kú obl'úbenost' detských lekárok, prácu žien ,,na poli sociálnozdravotnom “, prácu lekárok v poradniach pre matky s det'mi a pre tehotné, kde práve ženy ako

80 JESENSKÁ, Zora. O obmedzení vysokoškolského štúdia žien. In Živena, 1941, roč. 31, č. 11-12, s. 320-327.

81 ,..., napred sa íst' musí!“ In Živena, 1941, roč. 31, č. 11-12, s. 327-334.

82 OTTLYKOVÁ-KOHÚTOVÁ, Edita. „,..., napred sa íst’ musí!“ In Živena, 1941, roč. 31, č. 11-12, s. 327-328. Edita Ottlyková (*1899-† 1974) - lekárka. 
lekárky poskytujú dôverné prostredie a intimitu pre jednoduché, najmä vidiecke ženy: ,, Bola by chyba zabraňovat'ženským prácu, ku ktorej majú prirodzené vlohy a nadanie len preto, že sa vymyká z kruhu domácnosti, rodiny. "Proti prepúšt’aniu vzdelaných žien autorka argumentovala najmä tým, že ženy akademičky majú hmotné aj duchovné prostriedky, aby sa popri zamestnaní mohli venovat' aj rodine, čo ale neplatí pre "tisice žien a matiek, ktoré pracujú v továrňach, alebo pri stavbách tol'ko hodín ako muž, a ráno pred nastúpením práce a večer po návrate domov musia obslúžit' muža, navarit', oprat' a obšivat' pre celú rodinu, a sotva sa vyspia od starosti a nedostatku času, a to všetko pre pár korún, lebo mužov zárobok nestači zakryt' životné potreby rodiny “ ${ }^{83} \mathrm{~V}$ tret’om príspevku sa vysokoškolsky vzdelaná žena (profesorka) otvorene priznala, že „pre prácu $v$ domácnosti nemá zmyslu, ani nadania“, ale nemala by ho ani vtedy, keby nemala vysokoškolské vzdelanie. Autorka ako profesorka zdôraznila význam žien - učiteliek a profesoriek vo vzdelávaní dievčat aj chlapcov. ${ }^{84} \mathrm{~V}$ štvrtom príspevku hudobníčka dr. Zdenka Bokesová opätovne zdôraznila význam vysokoškolského štúdia pre ženy, ,ktoré idú na vysokú školu z vlastného, vnútorného duchovného popudu“. Pripustila, že štúdium „premení náhl’ad na rodinu, na manželstvo a úlohy rodičovské, ale nie v tom zmysle, že by sme sa ich stránili “. ${ }^{85}$

V júni 1941 uverejnila redakcia Novej ženy výzvu Spolku slovenských katolíckych akademičiek na anketu o štúdiu slovenských dievčat. Touto výzvou sa obrátili na verejne činné ženy, ktoré mali ,najlepšie možnosti posúdit’ všetky kladné i záporné hodnoty štúdia“ a na matky, ktoré „najlepšie poznajú svoje dcéry". ${ }^{86}$ Diskusia o vysokoškolskom štúdiu žien sa tak presunula aj na pôdu Novej ženy.

V prvom príspevku sa redaktorka M. V. (pravdepodobne Margita Václavíková) prihovorila slovenským ženám - matkám, aby sa vážne zamysleli nad problémom vzdelávania dievčat. Dôraz položila najmä na dilemu, či je štúdium dievčat „otázkou chlebovou a s tým spojené s problémom konkurencie“ s mužmi, alebo „štúdium vyviera $z$ vnútornej potreby po duchovnom vzraste“. Zároveň zdôraznila nevyhnutnost' zamysliet' sa nad potrebou zabezpečenia budúcnosti dievčat aj pre prípad, že by sa nevydali a zostali slobodné. Upozornila na fakt, že ak by sa na Slovensku zabránilo dievčatám doštudovat', mnohé by odišli do

83 JESENSKÁ-MASÁROVÁ, Mária. ,..., napred sa íst' musí!““In Živena, 1941, roč. 31, č. 11-12 (november-december), s. 328-332. Mária Jesenská-Masárová (*1906 - † 2008) - priekopníčka pediatrie v oblasti Turca, vydala sa do známej rodiny Jesenských.

84 PROFESORKA. ,..., napred sa íst’ musí!“ In Živena, 1941, roč. 31, č. 11-12, s. 332-333.

85 BOKESOVÁ, Zdenka. ,..., napred sa íst’ musí!“'In Živena, 1941, roč. 31, č. 11-12, s. 333-334. Zdenka Bokesová-Hanáková (* 1911 - † 1962) - hudobná kritička a historička.

86 Anketa. In Nová žena, 22. júna 1941, roč. 4, č. 25, s. 3; Anketa o štúdiu slovenských dievčat. In Nová žena, 29. júna 1941, roč. IV, č. 26, s. 9. 
cudziny, kde by školu dokončili. Nabádala ženy, aby sa zapojili do ankety, najmä vysokoškolsky vzdelané ženy, ktoré po vydaji zanechali prácu, aby napísali o význame štúdia aj pre ich rodinný život. ${ }^{87}$

Ďalšia pravidelná prispievatel'ka Mira Zl'avská tiež vyzvala ženy, aby zaujali stanovisko k tomuto problému a nenechali ,prejst' čas, aby potom rezignovane, bez t’archy zodpovednosti pre nasledujúce generácie žien, vhupli do zákonných prúdov formovaných výlučne mužmi “. Autorka požadovala zainteresovanie žien na riešení tejto otázky. Sama sa jednoznačne vyslovila za štúdium dievčat. Podl'a nej by bolo krajne nespravodlivé, ak by sa zakázala duševná práca žien (úradníčky, učitel'ky, profesorky lekárky), ale „,na poli fyzickej práce by rol'ničkam, krajčirkam, nádenničkam, posluhovačkám atd’. bolo povolené pracovat!" Tento jav by bol podl'a jej názoru len potvrdením „,duševnej menejcennosti žien “. Povzbudila slovenské ženy, aby študovali a pracovali. Na svoju dobu vel'mi moderne požadovala rovnakú mzdu (,rovnocennú odmenu“) pre ženy aj pre mužov v zamestnaní. Autorka porovnávala reálne životné možnosti žien a mužov. Muži mohli pracovat' popri rodine, cestovali, venovali sa zál'ubám, napĺn̆ali svoje túžby. Ženy len skromne krčili hlavy. Odmietla zažitý výrok z minulého storočia, že žene treba dat' len varešku a koryto šiat. Podl'a možností mala byt' „,každá slovenská žena vzdelaná “, zároveň však dodala, že nie každá vzdelaná žena mala byt' zárobkovo činná. ${ }^{88}$

\section{Závery}

Odklon od demokratických politických princípov Československej republiky sa prejavil v období autonómie a po vyhlásení Slovenského štátu zásadnými zmenami v postavení slovenských žien v politickom a spoločenskom živote krajiny.

Vládnuce konzervatívne kruhy HSL'S sa snažili v politickej praxi a $\mathrm{v}$ reálnom živote presadit' svoje konzervatívne predstavy o tzv. prirodzenom poslaní ženy v spoločnosti. V reálnej politike režimu sa tieto ideálne predstavy prejavili prepúšt’aním vydatých žien zo zamestnania v štátnej a verejnej službe, obmedzovaním alebo komplikovaním stredoškolského vzdelávania dievčat (zrušením koedukácie, reformovaním stredoškolského vzdelávania) a návrhom na dočasné obmedzenie vysokoškolského štúdia dievčat na Slovenskej univerzite v Bratislave.

Hlavným argumentom pre realizáciu jednotlivých opatrení namierených proti ženám v oblasti vzdelávania a zamestnávania bolo najmä volanie po návrate slovenských žien do rodín - k manželstvu a materstvu. Žena sa mala realizovat’ len

87 M. V. Na margo ankety našich akademičiek. In Nová žena, 27. júla 1941, roč. 4, č. 30, s. 7.

88 ZL'AVSKÁ, Mira. K ankete študovania žien. In Nová žena, 19. októbra 1941, roč. 4, č. 42, s. 3-4. 
v súkromnej sfére svojho manželstva a rodiny. Jej vzdelávanie a výchova mali byt' podriadené tejto ,prirodzenej “ úlohe v živote.

Dievčatá sa mali ,učit" domáce práce, vedeniu domácností a hospodárstiev a starostlivosti o diet'a. Vzdelávanie dievčat malo byt' zredukované a podriadené praktickým potrebám rodinného života. Ciel'om návrhu obmedzit' vysokoškolské vzdelávanie dievčat bolo tiež zredukovat' počet ženských absolventiek univerzity, a tým eliminovat' potenciálnu konkurenciu pre mužských poslucháčov. Aj ked' sa v diskusiách a dôvodovej správe k návrhu zákona opät' zdôrazňovala „prirodzená úloha a poslanie“ ženy v rodine, v konečnom dôsledku bol tento návrh motivovaný snahami vyriešit’ pálčivé sociálne problémy nového štátu, najmä vysokú nezamestnanost' štátnych úradníkov, vysokoškolských absolventov a učitel'ov. Prepustenie vydatých žien z verejnej a štátnej služby prinieslo mnohým rodinám pokles životnej úrovne, vzdelaným učitel'kám a úradníčkam stratu sebaúcty a dôležitosti. Zrušenie koedukácie viedlo k zníženiu počtu študentiek na gymnáziách a učitel'ských ústavoch.

Návrh vládneho nariadenia na obmedzenie vysokoškolského štúdia žien sa nepodarilo vláde presadit' kvôli rozhodnému odporu akademickej obce, odborníkov z radov profesorov a právnikov, ako aj samotných žien, ktoré sa v rozsiahlych tlačových kampaniach postavili proti tomuto návrhu. Počet zapísaných poslucháčok na Slovenskej univerzite v rokoch 1939 - 1944 postupne rástol. Ich štúdium ale nebolo bezproblémové a narážalo najmä na zložité sociálne a politické pomery $\mathrm{v}$ krajine.

* Príspevok vznikol pri riešení grantovej úlohy MŠ SR VEGA č. 1/0113/17 Populačná a rodinná politika na Slovensku v 20. a 21. storočí.

\section{BEMÜHUNGEN UM BESCHRÄNKUNG DES HOCHSCHULSTUDIUMS DER FRAUEN IN DER ZEIT DES SLOWAKISCHEN STAATES}

\section{EVA Š K O RVA N K O V Á}

Nach der Autonomiekundgebung und nach der Entstehung des Slowakischen Staates bemühte sich die herrschende volksparteiische Elite, ihre konservativen Ideen über die sog. natürliche Berufung der Frau in der Gesellschaft auch im wirklichen Leben durchzusetzen. In der realen Regimepolitik äußerten sich diese idealen Vorstellungen durch die Kündigung der verheirateten Frauen bei dem staatlichen und öffentlichen Dienst, durch Aufhebung der Koedukation, durch Beschränkung oder Regelung der Mittelschulbildung der Mädchen und durch das Vorhaben der zeitweisen Beschränkung des Hochschulstudiums 
an der Slowakischen Universität in Bratislava. Das Hauptargument für die Realisierung der einzelnen Maßnahmen im Bereich der Ausbildung und Beschäftigung der Frauen war vor allem der Ruf nach deren Rückkehr in die Familie - zur Ehe, zur Mutterschaft und Haushaltspflege. Der Tätigkeitsbereich für die Frauen war nur im privaten Gebiet der Ehe und Familie bestimmt. Ihre Ausbildung und Erziehung sollten dieser „natürlichen“ Aufgabe im Leben ganz unterstellt sein. Die Mädchen sollten die Hausarbeiten, den Haushalt und die Wirtschaft richtig und ökonomisch führen lernen und sich ordentlich für die Rolle der Mutter vorbereiten. Die Ausbildung der Mädchen sollte reduziert und den praktischen Bedürfnissen des familiären Lebens und der Mutterschaft untergestellt werden. Mit der Beschränkung der Hochschulbildung der Mädchen an der philosophischen, naturwissenschaftlichen und medizinischen Fakultät sollte man die Zahl der weiblichen Absolventinnen der Universität reduzieren und damit eine potentielle Konkurrenz für die Männer auf dem Arbeitsmarkt beseitigen. Aus dem Jurastudium sollten die Frauen ganz und gar ausgeschieden werden.

Mgr. Eva Škorvanková, PhD.

Katedra všeobecných dejín

Filozofická fakulta UK

Gondova 2, 81499 Bratislava

e-mail: eva.skorvankova@uniba.sk 